\title{
Hubungan Dukungan Keluarga Terhadap Kesehatan Lansia Dalam Pencegahan Covid-19
}

\author{
Penulis: \\ Savitri Gemini ${ }^{1,}$ \\ Mona Rahayu Putri ${ }^{2}$ \\ Ikbal Maulana ${ }^{3}$
}

\begin{abstract}
Afiliasi :
Institut Kesehatan Mitra

Bunda
\end{abstract}

Korespondensi:

putrimonarahayu@gmail

.com

Histori Naskah:

Diajukan: 2022-01-18

Disetujui: 2022-01-19

Publikasi: 2022-01-21

\begin{abstract}
Abstrak:
Virus Corona telah menginfeksi lebih dari 100.000 penduduk dunia dan sekitar 4.000 orang di antaranya dinyatakan meninggal dunia. Di Indonesia persentase usia $\geq 60$ tahun yang terkonfirmasi positif terkena covid-19 sebesar $(10,7 \%)$. Dalam upaya memberikan perlindungan bagi lansia dan untuk mengurangi kasus terjadinya covid-19 pada lansia, keluarga mempunyai peranan penting dalam upaya pencegahan penyebaran penyakit covid-19, dimana keluarga dapat memberikan dukungan kepada anggota keluarganya serta menanamkan budaya untuk hidup bersih dan sehat, membiasakan cuci tangan dan memakai masker.

Tujuan penelitian ini adalah untuk mengetahui hubungan dukungan keluarga terhadap kesehatan lansia dalam pencegahan covid-19 di UPT. Puskesmas Baloi Permai Kota Batam.

Penelitian analitik dengan rancangan cross sectional. Responden dalam penelitian ini adalah 67 responden Lansia. Teknik penarikan sample yang digunakan adalah non-probability sampling yaitu dengan purposive sampling Hasil uji statistic menggunakan Chi-Square Test diperoleh nilai $(\mathrm{p}$ value $)=$ $(0,003<0,05)$. Kesimpulan dari penelitian ini, dukungan keluarga dapat mempengaruhi kesehatan lansia dalam pencegahan covid-19. Dukungan keluarga dapat mempengaruhi kesehatan lansia dalam pencegahan covid-19.
\end{abstract}

Kata kunci: Dukungan keluarga, keseahatn lansia, pencegahan, Covid-19

\section{Pendahuluan}

WHO mengatakan Rata-rata dibutuhkan 5-6 hari sejak seseorang terinfeksi virus namun bisa memakan waktu hingga 14 hari untuk menunjukkan gejala. Covid-19 dapat menyebar dari kontak dekat satu sama lain, biasanya dalam jarak 1 meter melalui cipratan dari mulut atau hidung orang yang terinfeksi dalam partikel cairan kecil ketika mereka batuk, bersin, berbicara, bernyanyi atau bernapas Orang juga dapat terinfeksi dengan menyentuh permukaan yang telah terkontaminasi virus saat menyentuh mata, hidung, atau mulut tanpa membersihkan tangan (World Health Organization 2020)

Virus yang dikenal dengan sebutan severe acute respiratory syndrome-related coronavirus-2 (SARSCoV-2) atau Coronavirus Disease 2019 (Covid-19). Virus ini telah menyebar ke berbagai negara, termasuk Indonesia. Mewabahnya virus Covid-19 yang telah banyak merenggut jiwa ini muncul diakibatkan oleh peristiwa zoonosis (perpindahan virus dari hewan ke manusia). Covid-19 bisa menyerang siapa saja. Mulai dari bayi, anak-anak, hingga orang dewasa, termasuk ibu hamil dan ibu menyusui serta lansia. Karenanya, pada tanggal 11 Maret 2020 Organisasi Kesehatan Dunia (WHO) menetapkan Covid-19 sebagai pandemi (World Health Organization 2020)

Kementrian Kesehatan RI tahun 2019 merilis data bahwa pada tahun 2010 jumlah penduduk lansia mencapai 18 juta jiwa (7,6 \%), meningkat pada tahun 2019 menjadi 25,9 juta jiwa (9,7 \%), jumlah penduduk lansia tahun 2020 terdapat 27,08 juta jiwa tahun 2025 sebesar 33,69 juta jiwa, tahun 2030 sebesar 40,95 juta jiwa, dan diperkirakan pada tahun 2035 mencapai 48,2 juta jiwa (15,8\%) (Kementrian Kesehatan republik Indonesia 2020) 
Kementrian Kesehatan RI tahun 2019 merilis data bahwa pada tahun 2010 jumlah penduduk lansia mencapai 18 juta jiwa (7,6 \%), meningkat pada tahun 2019 menjadi 25,9 juta jiwa (9,7 \%), jumlah penduduk lansia tahun 2020 terdapat 27,08 juta jiwa tahun 2025 sebesar 33,69 juta jiwa, tahun 2030 sebesar 40,95 juta jiwa, dan diperkirakan pada tahun 2035 mencapai 48,2 juta jiwa $(15,8 \%)$ (Kementrian Kesehatan republik Indonesia 2020)

Jumlah lansia yang ada di Kota Batam usia 45-59 tahun 166.996 jiwa, usia 60-69 tahun 41.165 jiwa, usia > 70 tahun 10.482 jiwa (Dinas Kesehatan Kota Batam 2020). Di kota batam lansia yang terkonfrimasi Covid-19 pada usia 46-55 tahun sebanyak 930 orang, usia 56-65 tahun sebanyak 423 orang sedangkan pada usia $>65$ tahun jumlah yang terkonfirmasi positif sebanyak 133 orang (Dinas kesehatan Kota Batam 2021)

Data dari 21 Puskesmas didapatkan penderita Covid-19 sebanyak 6.223 jiwa, penyakit Covid-19 tertinggi terdapat di UPT. Puskesmas Baloi Permai dengan jumlah sebanyak 942 jiwa dan 77 orang diantaranya adalah lansia yang berusia $>60$ tahun, di UPT. Puskesmas Baloi Permai juga memiliki 27.556 jiwa lansia dimana pada usia 45-59 tahun berjumlah 21.025 jiwa, usia $>60$ tahun berjumlah 5.203 jiwa dan usia > 70 tahun berjumlah 1.328 jiwa (Dinas kesehatan Kota Batam 2021)

Faktor yang membuat lansia rentan tertular Covid-19, karena lansia mengalami penurunan kapasitas fungsional hampir pada seluruh sistem tubuh termasuk imunitasnya. Ditambah dengan banyaknya lansia yang mempunyai penyakit bawaan seperti penyakit autoimun, diabetes, tekanan darah tinggi, kanker dan jantung. Berbagai fakta tersebut dan fakta bahwa di berbagai negara korban meninggal karena Covid-19 didominasi oleh lansia, menunjukkan lansia Indonesia pada posisi yang sangat rentan (Probosuseno, 2020) dalam (Hakim 2020)

Peran keluarga semakin instrumental dalam kehidupan berbangsa dan bernegara. Lebih-lebih ditengah melonjaknya angka kasus penularan Covid-19, Pemerintah justru berencana memberlakukan tatanan hidup baru atau yang populer dikenal dengan istilah new normal. Peran kontributif keluarga dalam menghadapi permasalahan Covid-19, bisa diawali dengan mengoptimalkan struktur keluarga khususnya kepala keluarga. Peran fungsional kepala keluarga dimasa pandemi covid-19 adalah kemampuan mendisiplinkan seluruh perilaku anggota keluarganya. Mengingat kunci utama agar aman dari penularan Covid-19 adalah berperilaku disiplin. Peran strategis kepala keluarga untuk mendisiplinkan perilaku anggotanya dapat dipandang sebagai indikator pengukur keberhasilan keluarga dalam membantu pemerintah menghentikan panyebaran Covid-19. Efektivitas pendisiplinan yang dilakukan kepala keluarga terhadap anggotanya tidak mungkin terpisahkan dari kedudukannya sebagai tokoh sentral dan panutan di dalam struktur masyarakat terkecil itu. Karena posisinya sebagai pemimpin (leader), kepala keluarga sebenarnya mempunyai otoritas atau kekuasaan tertinggi untuk meminta ketaatan seluruh anggota keluarganya supaya selalu mematuhi protokol kesehatan yang ditetapkan Pemerintah menyangkut Covid-19 (Santika 2020).

\section{Studi Literatur}

1. Konsep Dasar Lansia

Usia lanjut adalah suatu proses alami yang tidak dapat dihindari oleh manusia. Lanjut usia ditandai dengan perubahan fisik, emosional, dan kehidupan seksual (Maramis 2016). Gejala-gelaja kemunduranfisik seperti merasa cepat capek, stamina menurun, badan menjadi membongkok, kulit keriput, rambut memutih, gigi mulai rontok, fungsi pancaindra menurun, dan pengapuran pada tulangrawan (Maramis 2016)

2. Dukungan Keluarga 
Dukungan keluarga adalah sebuah proses yang terjadi sepanjang masa kehidupan. Sifat dan jenis dukungan berbeda dalam berbagai tahap-tahap siklus kehidupan. Dukungan keluarga dapat berupa dukungan sosial internal, seperti dukungan dari suami istri atau dukungan dari saudara kandung dan dapat juga berupa dukungan keluarga eksternal bagi keluarga inti. Sebagai akibatnya, hal ini meningkatkan kesehatan dan adaptasi keluarga (Friedman 2010).

\section{Konsep Covid-19}

Covid-19 adalah penyakit menular yang diakibatkan infeksi virus coronavirus jenis baru. Penyakit ini diketahui muncul pertama kali di Wuhan, Cina pada Desember 2019 (WHO, 2020) dalam (M. K. Sari 2020) Covid-19 merupakan penyakit pernapasan akut yang menjadi pandemik global dan disebabkan oleh novel coronavirus atau SAR-Cov-2 (Erlich, 2020) dalam (M. . Sari 2020).

\section{Metode Penelitian}

Penelitian ini termasuk jenis penelitian analitik dengan design atau rancangan cross sectional. Cross sectional adalah jenis penelitian yang menekankan waktu pengukuran/ observasi data variabel independen dan dependen hanya satu kali pada satu saat

\section{Hasil}

\section{a. Analisis Univariat}

Distribusi Frekuensi Dukungan Keluarga di UPT. Puskesmas Baloi Permai Kota Batam Tahun 2021 menunjukkan bahwa sebagian besar dukungan keluarga lansia kurang baik dengan jumlah 40 Lansia $(59,7 \%)$.

\section{b. Analis Bivariat}

Hubungan Dukungan Keluarga Terhadap Kesehatan Lansia Dalam Pencegahan Covid-19 di UPT. Puskesmas Baloi Permai Kota Batam Tahun 2021. Berdasarkan uji statistik menunjukkan bahwa dari 67 lansia yang kurang baik terjadi pada lansia yang kurang baik dalam mendapatkan dukungan dari keluarga dengan jumlah sebanyak 28 lansia $(70,0 \%)$. Jadi ditarik kesimpulan semakin besar dukungan keluarga semakin besar pula kesehatan lansia dalam pencegahan covid-19

\section{Pembahasan}

\section{Dukungan Keluarga}

Berdasarkan hasil penelitian diketahui bahwa sebagian besar Dukungan Keluarga di UPT. Puskesmas Baloi Permai Kota Batam kurang baik yaitu sebanyak 40 Lansia $(59,7 \%)$.

Hasil penelitian ini sejalan dengan penelitian yang dilakukan oleh Santika, I Gusti Ngurah (2020) yang berjudul Optimalisasi Peran Keluarga Dalam Menghadapi Persoalan Covid-19: Sebuah Kajian Literatur. Bahwa optimalisasi peran keluarga dalam menghadapi persoalan Covid-19 dapat diketahui dari (1) kemampuan mendisiplinkan seluruh perilaku anggotanya, (2) mengedukasi atau mendidik anak-anaknya supaya mematuhi protokol kesehatan yang ditetapkan Pemerintah, (3) mempersiapkan dan memenuhi kebutuhan hidup anggotanya, (4) menanamkan kebiasaan pada anggotanya untuk senantiasa mempraktikkan pola hidup sehat dengan berolahraga secara rutin dan teratur, (5) memelihara kesehatan mental anggotanya, (6) saling memotivasi dan menguatkan, (7) sosial kemasyarakatan dalam upaya pemenuhan kebutuhan dasar manusia sebaga mahkluk sosial. 
Hasil penelitian ini sejalan dengan penelitian yang dilakukan oleh Ashidiqie, Mughni Labib (2020) yang berjudul Peran Keluarga Dalam Mencegah Corona Virus Disease 2019. Bahwa dengan menjalankan peran dan fungsinya secara optimal dan baik, maka keluarga dapat mencegah para anggotanya dari persebaran wabah Covid-19.

Hasil penelitian sejalan dengan penelitian yang dilakukan oleh Alvita, Galia Wardha, et al, (2020) yang berjudul Pemberdayaan Dukungan Keluarga dalam Meningkatkan Pencegahan Covid-19 Di Masyarakat Kabupaten Demak. Bahwa Keluarga memiliki peran penting dalam upaya pencegahan penyakit Covid-19 yaitu dengan memberikan dukungan keluarga berupa dukungan infomasional, dukungan instrumental, dukungan emosional dan dukungan penghargaan.

Hasil penelitian sejalan dengan penelitian yang dilakukan oleh Satria, Beni, et al, (2021) yang berjudul Hubungan Karakteristik Responden Dan Dukungan Keluarga Dengan Kepatuhan Terhadap Protokol Kesehatan Pencegahan Covid-19. Hasil penelitian dengan 393 responden menunjukkan kurang mendapatkan dukungan keluarga sebanyak 210 responden $(53,4 \%)$.

Dukungan keluarga adalah sebuah proses yang terjadi sepanjang masa kehidupan. Sifat dan jenis dukungan berbeda dalam berbagai tahap-tahap siklus kehidupan. Dukungan keluarga dapat berupa dukungan sosial internal, seperti dukungan dari suami istri atau dukungan dari saudara kandung dan dapat juga berupa dukungan keluarga eksternal bagi keluarga inti. Sebagai akibatnya, hal ini meningkatkan kesehatan dan adaptasi keluarga (Friedman 2010).

Dalam upaya memberikan perlindungan bagi lansia dan untuk mengurangi kasus terjadinya covid-19 pada lansia, keluarga mempunyai peranan penting dalam upaya pencegahan penyebaran penyakit covid-19, dimana keluarga dapat memberikan dukungan kepada anggota keluarganya serta menanamkan budaya untuk hidup bersih dan sehat, membiasakan cuci tangan dan memakai masker. Dukungan keluarga dapat berupa dukungan informasional, instrumental, penghargaan dan emosional. Dalam Dukungan informasional, keluarga bisa memberikan informasi tentang penyakit corona kepada anggota keluargnya, mengingatkan jika lupa cuci tangan atau lupa memakai dan membawa masker. Untuk dukungan instrumental keluarga dapat menyediakan masker untuk keluarganya, menyediakan handsanitizer/ sabun atau alat cuci tangan, menyediakan makanan bergizi, menjaga kebersihan rumah dan lain sebagianya. Untuk dukungan penghargaan keluarga dapat selalu memberikan pujian bagi anggotanya yang tetap mempertahankan prinsip $3 \mathrm{M}$ tersebut sehingga dapat meningkatkan motivasi mereka. Sedangkan untuk dukungan emosional, keluarga memberikan kasih sayang dan perhatian pada anggota keluarga yang lain yang sedang isolasi mandiri atau yang sedang berobat karena Covid19 (Alvita et al. 2021).

\section{Kesehatan Lansia}

Berdasarkan hasil penelitian diketahui bahwa sebagian besar Kesehatan Lansia di UPT. Puskesmas Baloi Permai Kota Batam kurang baik yaitu sebanyak 37 Lansia $(55,2 \%)$.

Hasil penelitian sejalan dengan penelitian yang dilakukan oleh Satria, Beni, et al, (2021) yang berjudul Pemberdayaan Dukungan Keluarga Terhadap Peningkatan Kepatuhan Penerapan Protokol Kesehatan Pencegahan Covid-19. Hasil penelitian dengan 393 responden menunjukkan yang tidak patuh terhadap protokol kesehatan yaitu berjumlah 235 responden $(59,8)$.

Hasil penelitian sejalan dengan penelitian yang dilakukan oleh Abidin, Ahmad Zainal, Errix Kristian Julianto (2020) yang berjudul Hubungan Fungsi Pemeliharaan Kesehatan Keluarga Dengan Pencegahan Penularan Covid-19 Bagi Lansia Di Desa Kadungrejo Baureno Bojonegoro. Hasil 
penelitian dengan 102 responden mayoritas pencegahan penularan covid19 bagi lansia dengan kategori kurang yaitu sebanyak 51 responden (50\%).

Hasil penelitian sejalan dengan penelitian yang dilakukan oleh Ginting, Tarianna, et al (2021) yang berjudul Kepatuhan Pedagang Pasar Pagi Dalam Melaksanakan Protokol Kesehatan Pencegahan Covid-19. Hasil penelitian dengan Dari 133 responden yang diteliti terdapat 120 responden yang memiliki sikap yang baik, pedagang yang tidak patuh sebanyak 64 orang $(53,3 \%)$, dan responden yang patuh sebanyak 56 orang $(46,6 \%)$. Dari 13 responden yang memiliki sikap yang cukup, reponden yang tidak patuh sebanyak 10 orang $(76,9 \%)$, dan responden yang patuh sebanyak 3 orang $(23,1,8 \%)$

Kesehatan merupakan hal yang sangat penting dalam kehidupan manusia, sehat juga merupakan keadaan dari kondisi fisik yang baik, mental yang baik, dan juga kesejahteraan sosial, tidak hanya merupakan ketiadaan dari penyakit atau kelemahan (WHO, 1948) dalam (Krisna Triyono and K. Herdiyanto 2018)

Dalam upaya menjaga kesehatan lansia serta pencegahan penyebaran penyakit covid-19 maka lansia di anjurkan untuk tetap tinggal di rumah/panti wreda/senior living dan melakukan kegiatan rutin sehari-hari, menjaga jarak (1 meter atau lebih) dengan orang lain, hindari bersentuhan, bersalaman atau bercium pipi, serta jauhi orang sakit, menjaga kebersihan tangan dengan cara sering cuci tangan dengan sabun atau dengan hand sanitizer, serta hindari menyentuh mata, hidung dan mulut, lansia maupun pendamping selalu memakai masker, bila batuk atau bersin, tutup hidung dan mulut dengan lengan atas bagian dalam atau tisu, istirahat dan tidur yang cukup, minimal 6-8 jam sehari atau lebih, menjaga lingkungan tempat tinggal agar sirkulasi udara baik dan terpapar sinar matahari, makan makanan dengan gizi seimbang (cukup karbohidrat, protein, lemak, vitamin dan mineral). Selain itu minum yang cukup, dan bila diperlukan minum multi vitamin serta hindari dan hentikan merokok (Kementrian Kesehatan republik Indonesia 2020).

Selain hal di atas lansia juga di anjurkan untuk tetap melakukan aktivitas fisik yang cukup di rumah, seperti olahraga ringan didalam rumah menggunakan video tutorial, mengurus tanaman disekitar rumah sambil berjemur di pagi hari, membuat kreativitas tangan untuk melatih motorik, membaca buku dan mengisi teka teki silang untuk mencegah penurunan kognisi, beribadah, memasak makanan yang disukai atau aktivitas lain yang menyenangkan, jauhi keramaian, perkumpulan dan kegiatan sosial, seperti arisan, reuni, rekreasi, pergi berbelanja dan lain-lain, menjaga kesehatan jiwa dan psikososial lansia dengan cara menghindari berita/informasi yang memancing rasa khawatir berlebihan, dan lebih banyak mengakses berita/informasi positif yang memberi sugesti dan keyakinan baik serta membangkitkan optimisme.

Selain itu tetap menjalin komunikasi dan silaturahmi dengan anak, cucu dan kerabat lain maupun teman melalui komunikasi jarak jauh, atau mengatur jadwal kunjungan dengan tetap memperhatikan protokol pencegahan penularan, dan untuk lansia yang mempunyai penyakit kronis (seperti Hipertensi, Diabetes atau penyakit menahun lainya) dapat melakukan pemantauan kesehatan mandiri di rumah menggunakan alat kesehatan sederhana, seperti alat tensimeter digital, thermometer digital, alat cek darah sederhana. Selain itu pastikan obat-obatan rutin yang harus diminum setiap hari dalam jangka waktu lama tetap cukup persediaannya di rumah dan (Kementrian Kesehatan republik Indonesia 2020).

Berdasarkan hasil di atas maka peneliti berasumsi bahwa kesehatan lansia dalam pencegahan covid19 di UPT. Puskesmas Baloi Permai Kota Batam sebagian besar lansia kurang baik dalam kesehatan pencegahan covid-19 hal ini dikarenakan kurangnya dukungan keluarga terhadap lansia, sehingga 
lansia kurang mendapatkan motivasi dalam melakukan pencegahan covid-19 terutama dalam melakukan aktivitas fisik atau olahraga serta dalam pemeriksaan kesehatan padahal hal ini perlu dilakukan dimana hal ini bertujuan untuk mencegah terjadinya covid-19 pada lansia.

\section{Kesimpulan}

Setelah dilakukan penelitian dan dilakukan pengolahan data oleh peneliti yang berjudul Hubungan Dukungan Keluarga Terhadap Kesehatan Lansia Dalam Pencegahan Covid-19 di UPT. Puskesmas Baloi Permai Kota Batam Tahun 2021 dapat diambil kesimpulan bahwa sebagian besar lansia kurang mendapat dukungan keluarga dengan jumlah 40 Lansia (59,7\%), sebagian besar kesehatan lansia kurang baik dengan jumlah 37 Lansia $(55,2 \%)$. Terdapat hubungan yang signifikan antara dukungan keluarga terhadap kesehatan lansia dalam pencegahan covid-19 di UPT. Puskesmas Baloi Permai Kota Batam Tahun 2021, dengan uji statistic Chi-Square di peroleh nilai $p$-value sebesar $=(0,003<$ $0,05)$.

\section{Referensi}

Alvita, Galia Wardha, Sri Hartini, Biyanti Dwi Winarsih, and Noor Faidah. 2021. "Pemberdayaan Dukungan Keluarga Dalam Meningkatkan Pemahaman Pencegahan Covid-19 Di Masyarakat Kabupaten Demak." 4(1):10-20.

Dinas kesehatan Kota Batam. 2021. "Data Jumlah Penderita Covid-19."

Dinas Kesehatan Kota Batam. 2020. "Data Jumlah Lansia."

Friedman. 2010. Buku Ajar Keperawatan Keluarga: Riset, Teori \& Praktik. Jakarta: EGC.

Hakim, L. .. 2020. Pelindungan Lanjut Usia Pada Masa Pendemi Covid-19.

Kementrian Kesehatan republik Indonesia. 2020. Profil Kesehatan Indonesia 2019. Jakarta.

Krisna Triyono, Samuel Dwi, and Yohanes K. Herdiyanto. 2018. "Konsep Sehat Dan Sakit Pada Individu Dengan Urolithiasis (Kencing Batu) Di Kabupaten Klungkung, Bali." Jurnal Psikologi Udayana 4(02):263. doi: 10.24843/jpu.2017.v04.i02.p04.

Maramis, R. 1. 2016. "Kebermakanaan Hidup Dan Kecemsan Dalam Mengdahapi Kematian Pada Lansia Di Panti Wedha Samarinda." Ejournal Psikologi 319-32.

Santika, I. Gusti Ngurah. 2020. "Optimalisasi Peran Keluarga Dalam Menghadapi Persoalan Covid19 : Sebuah Kajian Literatur.” 6(2):127-37.

Sari, M. .. 2020. "Sosialisasi Tentang Pencegahan Covid-19 Di Kalangan Siswa Sekolah Dasar Di SD Minggiran 2 Kecamatan Papar Kabupaten Kediri.” Jurnal Karya Abdi.

Sari, Melani Kartika. 2020. "Sosialisasi Tentang Pencegahan Covid-19 Di Kalangan Siswa Sekolah Dasar Di SD Minggiran 2 Kecamatan Papar Kabupaten Kediri.” Jurnal Karya Abdi 4(1):80-83.

World Health Organization. 2020. "Coronavirus." 